\title{
2015-2016 APSA Active and Award Committees
}

COUNCIL

President (2016-2017)

David A. Lake, University of California, San Diego

\section{President-Elect (2016-2017)}

Kathleen Thelen, Massachusetts Institute of Technology

Vice Presidents (2016-2017)

Janet Box-Steffensmeier, Ohio State University

Elaine Kamarck, Brookings Institution

Ian Shapiro, Yale University

\section{Treasurer (2015-2017)}

Taeku Lee, University of California, Berkeley

\section{Secretary (2016-2017)}

Marion Orr, Brown University

\section{Council Members 2015-2017}

Roxanne Euben, Wellesley College Amaney Jamal, Princeton University Brett Ashley Leeds, Rice University James Mahoney, Northwestern University Byron D'Andra Orey, Jackson State University

Bo Rothstein, University of Gothenburg Cameron Thies, Arizona State

University

Caroline Tolbert, University of Iowa

\section{Council Members 2016-2018}

Matt Barreto, University of California,

Los Angeles

Mark Crescenzi, University of North

Carolina, Chapel Hill

Omar Encarnación, Bard College

Kristian Gleditsch, University of Essex

Juliet Hooker, University of Texas,

Austin

Colleen Shogan, Library of Congress

Renée Van Vechten, University of

Redlands

Christina Wolbrecht, University of Notre

Dame

American Political Science Review Editor in Chief (2016-2019)

Thomas König, University of Mannheim
Perspectives on Politics Editor in Chief

(2009-2017)

Jeffrey Isaac, Indiana University, Bloomington

\section{Annual Meeting Program Cochairs \\ (2015-2016)}

Amaney Jamal, Princeton University

Susan Hyde, University of California, Berkeley

\section{Executive Director}

Steven Rathgeb Smith

\section{COUNCIL COMMITTEES}

\section{Executive Committee}

David Lake, University of California, San

Diego (President)

Kathleen Thelen, Massachusetts Institute of Technology (President-Elect)

Jennifer Hochschild, Harvard University

(Past President)

Taeku Lee, University of California, Berkeley (Treasurer)

Ashley Leeds, Rice University (2015-2017

Council)

Marion Orr, Brown University (2016-2017

Secretary)

Ian Shapiro, Yale University (Vice

President)

Colleen Shogan, Library of Congress (2016-2018 Council)

Renee Van Vechten, University of Redlands (2016-2018 Council)

\section{Audit Committee}

Chair: Caroline Tolbert, University of Iowa (2015-2017 Council)

Mark Crescenzi, University of North

Carolina, Chapel Hill (2016-2018 Council) David Lublin, American University

\section{Committee on Elections and Rules}

Chair: Janet Box-Steffensmeier, Ohio State University (2016-2017 Vice President) Marion Orr, Brown University (2016-2017 Secretary)

Christina Wolbrecht, University of Notre

Dame (2016-2018 Council)

\section{Publications Committee}

Chair: Ashley Leeds, Rice University (2015-2017 Council)
Roxanne Euben, Wellesley College (20152017 Council)

Kristian Gleditsch, University of Essex (2016-2018 Council)

Christina Wolbrecht, University of Notre Dame (2016-2018 Council)

\section{Membership and Professional \\ Development Committee}

Chair: Colleen Shogan, Library of Congress (2016-2018 Council)

Omar Encarnacion, Bard College (20162018 Council)

Byron D'Andra Orey, Jackson State University (2015-2017 Council)

\section{Conferences and Meetings Committee}

Chair: Ian Shapiro, Yale University (20162017 Vice President)

Bo Rothstein, University of Oxford (20152017 Council)

Amaney Jamal, Princeton University

(2015-2017 Council)

Juliet Hooker, University of Texas, Austin (2016-2018 Council)

\section{Teaching and Learning Committee}

Chair: Renee Van Vechten, University of

Redlands (2016-2018 Council)

Cameron Thies, Arizona State University

(2015-2017 Council)

James Mahoney, Northwestern University (2015-2017 Council)

\section{Public Engagement Committee}

Chair: Marion Orr, Brown University (2016-2017 Secretary)

Matt Barreto, University of California, Los Angeles (2016-2018 Council)

Elaine Kamarck, Brookings Institution (2016-2017 Vice President)

\section{Active Committees}

\section{TERM COMMITTEES}

\section{APSA/ASA Steering Committee}

Catherine Boone, London School of Economics, Cochair Carl LeVan, American University

Kennedy Mkutu, United States International University, Nairobi 


\section{Asia Workshop Steering Committee \\ John Aldrich, Duke University, Chair Edmund Malesky, Duke University Meredith Weiss, University at Albany SUNY}

\section{Middle East Workshop Steering Committee}

Term expiring August 31, 2019

Lisa Anderson, American University in Cairo, Chair

Mustapha K. Al Sayyid, American

University in Cairo

Nancy Bermeo, University of Oxford

Henry E. Brady, University of California,

Berkeley

Joseph G. Jabbra, Lebanese American

University

Amaney Jamal, Princeton University

\section{TLC Review Committee}

Audrey Haynes, University of Georgia, Chair

Janni Aragon, University of Victoria

Stephen Caliendo, North Central College

Michelle Deardorff, University of

Tennessee at Chattanooga

Terry Gilmour, Midland College

Stephen Meinhold, University of North

Carolina, Wilmington

Sherri Wallace, University of Louisville

\section{STATUS COMMITTEES}

\section{Committee on the Status of Asian}

Pacific Americans in the Profession

The Committee on the Status of Asian Pacific Americans in the Profession develops and promotes activities concerning the professional development of Asian American and Pacific Islander political scientists.

Term expiring August 31, 2019

James Lai, Santa Clara University

Carrie Liu Currier, Texas Christian University

Term expiring August 31, 2018

Julie Merseth, Northwestern University

Okiyoshi Takeda, Aoyama Gakuin

University

Term expiring August 31, 2017

Rebecca Dean, University of Texas, Arlington, Chair

Naomi Murakawa, Princeton University

\section{Committee on the Status of Blacks in} the Profession

The Committee on the Status of Blacks in the Profession develops and promotes activities concerning the professional development of African Americans within the discipline.
Term expiring August 31, 2019

Tyson King Meadows, University of

Maryland Baltimore County, Chair

Alexandra Moffett-Bateau, City University

of New York

Term expiring August 31, 2018

Porsha Cropper, Abt Associates

Clarissa Hayward, Washington University

in Saint Louis

Term expiring August 31, 2017

Michael Fauntroy, Howard University

Atiya Stokes-Brown, Bucknell University

Committee on the Status of Community Colleges in the Profession

Term expiring August 31, 2019

Elsa Dias, Pikes Peak Community College

Peter Bowman, Palomar College

Term expiring August 31, 2018

Sara Parker, Chabot College, Chair

Erin Richards, Cascadia College

Cammy Shay, Houston Community College

Term expiring August 31, 2017

Andrea Simpson, University of Richmond

Tressa Tabares, American River College

Committee on the Status of Contingent

Faculty in the Profession

Term expiring August 31, 2019

Catherine Guisan, University of

Minnesota, Chair

Julia Lau, Catholic University

Term expiring August 31, 2018

Veronica Czastkiewicz, Pikes Peak

Community College

Patricia Stapleton, Worcester Polytechnic

Institute

Peter Francia, East Carolina University

Term expiring August 31, 2017

Susan Orr, SUNY Brockport

Nathan Paxton, American University

\section{Committee on the Status of First}

Generation Higher Education Scholars

in the Profession

Term expiring August 31, 2019

Ricardo Ramirez, University of Notre

Dame

Tom K. Wong, University of California, San Diego

Term expiring August 31, 2018

Lorrie Frasure Yokley, University of

California, Los Angeles, Chair

Els De Graauw, CUNY-Baruch

Pei-te Lien, University of California,

Santa Barbara

Term expiring August 31, 2017

Virginia Gray, University of North

Carolina, Chapel Hill

Jessica Lavariega-Monforti,Pace University
Committee on the Status of Graduate

Students in the Profession

Terms expiring August 31, 2017

Brendan Mark, SUNY-Binghamton

Isabel Perera, University of Pennsylvania

Fabian Neuner, University of Michigan

Isabella Litke, Princeton University

Terms Expiring August 31, 2018

Melina Juarez, University of New

Mexico

Nakissa Jahanbani, SUNY-Albany

Christine Slaughter, University of

California Los Angeles

Bailey Fairbanks, Georgia State University

Committee on the Status of Latinos y

Latinas in the Profession

The Committee on the Status of Latinos

$y$ Latinas in the Profession develops and promotes activities concerning the professional development of Latino scholars within the discipline.

Term expiring August 31, 2019

Antonio Vazquez Arroyo, Rutgers University

David Leal, University of Texas, Austin

Term expiring August 31, 2018

Linda Mancillas, Georgia Gwinnett

College, Chair

Stephen Nuno, Northern Arizona University

Term expiring August 31, 2017

Maria Chavez, Pacific Lutheran University

Eric Juenke-Gonzalez, Michigan State University

Committee on the Status of Lesbians, Gays, Bisexuals and the Transgendered

This committee assesses the status oflesbian, gay, bisexual, and transgendered (LGBT) scholars in the profession, advances the research on LGBT issues, develops curriculum materials, and works to ensure tolerance toward LGBT political scientists.

Term expiring August 31, 2019

Stephen Engel, Bates College

Helma de Vries-Jordan, University of Pittsburgh at Bradford

Term expiring August 31, 2018

Jami Taylor, University of Toledo, Chair Rick Vallely, Swarthmore College

Term expiring August 31, 2017

Ellen Andersen, University of Vermont

Shawn Schulenberg, Marshall University

Committee on the Status of Women in the Profession

The Committee on the Status of Women in the Profession monitors and reports on the 
status of women in the profession, advances research on women and on issues of concern to women, develops and assesses curriculum materials, and works to ensure fair and equal treatment of women in the profession.

Term expiring August 31, 2019

Kathleen Cunningham, University of Maryland

Wendy Wong, University of Toronto

Term expiring August 31, 2018

Amy Atchison, Valparaiso University

Denise Walsh, University of Virginia

Term expiring August 31, 2017

Frances Rosenbluth, Yale University, Chair

Nadia Brown, Purdue University

PROGRAM AND ADVISORY

COMMITTEES

2016-2017 Nominating Committee

The Nominating Committee prepares a slate of candidates for elective office in the term expiring August 31, 2018.

Term expiring August 31, 2018 Terri Givens, Menlo College, Chair Jennifer Merolla, University of California, Riverside

Jennifer Pitts, University of Chicago

Term expiring August 31, 2017

Chris Gelpi, Ohio State University

Fred Harris, Columbia University

Tarek Masoud, Harvard University

\section{APSA Delegates to Other Associations}

\section{ACLS}

Richard Boyd, Georgetown University,

Term expiring December 31, 2018

National Coalition of History

Katherine Tenpas, Brookings Institution, no expiration

\section{Centennial Center Advisory Board}

The Centennial Center Advisory Board guides practices of the Centennial Center, oversees funds for Center activities, and makes final decisions on awarding of Centennial Center scholarships and grants.

Term expiring August 31, 2019

Sarah Childs, University of Bristol

Brandon Rottinghaus, University of Houston

Term expiring August 31, 2018

Joyce Kaufman, Whittier College, Chair Costas Panagopolous, Fordham University

Toni Michelle Travis, George Mason University

Term expiring August 31, 2017

Nina Therese Kasniunas, Goucher College Phil Keefer, Inter-American Development Bank

\section{Centennial Center Grant Review}

Committee

Pearl Dowe, University of Arkansas

Beth Whitaker, University of North

Carolina, Charlotte

\section{CFP Advisory Committee}

Doug Bereuter, President Emeritus, The Asia Foundation; former Member, U.S House of Representatives

Joan Claybrook, Public Citizen; former administrator NHTSA

Richard Cohen, Congressional Quarterly

Charles E. Cook, Jr., The Cook Report

The National Journal

Robert Dole, Special Counsel, Alston and

Bird; former Member, U.S. Senate

Ronald D. Elving, National Public Radio

Vic Fazio, Partner, Akin Gump; former

Member, U.S. House of Representatives CNN

David Gergen, Harvard University;

Lee H. Hamilton, Indiana University; former Member, U.S. House of Representatives

Gerald Kovach, former Senior Vice President, MCI

Richard Lugar, The Lugar Center; former

Member, U.S. Senate

David Price, Member, U.S. House of

Representatives

Cokie Roberts, ABC News; National Public Radio

Catherine Rudder, George Mason University

James Thurber, American University

Term expiring August 31,2019

Michelle Chin, Archer Center, University of Texas System

Menna Demessie, Congressional Black Caucus Foundation

Paul Light, New York University

\section{Committee on Departmental Services}

The Committee on Departmental Services oversees APSA's Departmental Services Program (DSP) which provides a forum for political science departments large and small to address common issues as well as plan and develop publications and services for chairs, faculty, and students. The program, overseen by the Committee on Departmental Services, supports political science teaching, scholarship, and service, and provides resources for department chairs.

Term expiring August 31, 2019

Holley Tankersley, Coastal Carolina University, Chair

Robert Pahre, University of Illinois, Urbana-Champaign
Term expiring August 31, 2018

Thomas Keck, Syracuse University George Lovell, University of Washington Term expiring August 31, 2017 Tony Messina, Trinity College, Hartford KC Morrison, Mississippi State University

\section{Committee on International Political} Science

The Committee on International Political Science recommends policy to the APSA council regarding internationalization of the association, develops relationships between American political science and political science in other nations, and oversees APSA's relationship with IPSA and other non-US national and international associations.

Term expiring August 31, 2019

David Mednicoff, University of Massachusetts, Amherst

Nadine Sika, American University in Cairo

Term expiring August 31, 2018

Karen Anderson, University of Southampton

Todd Eisenstadt, American University

Term expiring August 31, 2017

Hilde Coffee, Victoria University of Wellington, Chair

Laura Morales, University of Leicester

\section{Committee on Organized Sections}

The committee helps Organized Sections carry out their work and oversees the balance between Sections and APSA as a whole. As Section issues have become more routinized we expect that this Committee can function as a board that meets by e-mail and phone to address issues of compliance with APSA section procedures.

Term expiring August 31, 2019

Layna Mosley, University of North Carolina at Chapel Hill, Chair

Craig Volden, University of Virginia

Term expiring August 31, 2018

Carol Mershon, University of Virginia

Term expiring August 31, 2017

Juan Carlos Huerta, University of Texas, Corpus Christi

Lori Weber, California State University, Chico

\section{Committee on Professional Ethics, Rights, and Freedoms}

The responsibility of the Committee on Professional Ethics, Rights, and Freedoms is to protect the rights of political scientists and ensure that the ethical policies of the Association are followed. 
Term expiring August 31, 2019

Alison Brysk, University of California,

Santa Barbara

Kathleen Hancock, Colorado School of Mines

Term expiring August 31, 2018

Virginia Sapiro, Boston University, Chair

Michael Fortner, CUNY Graduate Center

Samantha Frost, University of Illinois, Urbana-Champaign

Term expiring August 31, 2017

David Campbell, University of Notre Dame

Susanna Wing, Haverford College

\section{Publications Committee}

The Publications Committee oversees and coordinates existing APSA publications, leads in setting standards for APSA journals and other publications, explores possible relationships with political science journals not sponsored by the association, and develops proposals for new publications, when appropriate.

Term expiring August 31, 2017

Alan Ware, Oxford University and University College, London

Ongoing

Phillip Ardoin, Appalachian State University ( $P S$ coeditor)

Paul Gronke, Reed College (PS coeditor)

Jeffrey C. Isaac, Indiana University, Bloomington (editor, Perspectives on Politics)

Thomas König (editor, American Political Science Review)

\section{Siting and Engagement Committee}

The Siting and Engagement Committee addresses the application of APSA siting policy for the APSA Annual Meeting, Teaching and Learning Conference, and any other major APSA meetings, and after a site has been selected by APSA, plans for a program of public engagement in the community.

Term expiring August 31, 2018 Rachael Cobb, Suffolk University, Chair Ted Davis, University of Delaware Ben McKean, Ohio State University Term expiring August 31, 2017 Melissa Michelson, Menlo College Justin Vaughn, Boise State University David Wilson, University of Delaware

\section{Small Research Grants Review Committee}

Mike Bosia, St. Michael's College, Chair Stefanie Chambers, Trinity College Helen Knowles, State University of New York, Oswego
Julia Maskivker, Rollins College

Gabriel Ondetti, Missouri State University

\section{Teaching and Learning Conference Committee}

The program committee for the Conference on Teaching and Learning in Political Science sets the themes for the meeting and oversees the formation of the conference tracks.

Term expiring 2017

Sara Moats, Florida International University, Chair

Kevin Anderson, Eastern Illinois University

Amber Dickinson, Oklahoma State University

Benjamin Gonzalez, Highline College

Elizabeth Matto, Rutgers University

Chad Raymond, Salve Regina University

Boris Ricks, California State University, Northridge

\section{Committee on Teaching and Learning in Political Science}

This committee develops and promotes activities within the association and the political science community regarding political science and the practices and policies of higher education, including undergraduate, graduate, professional, and life-long education. The committee also advises the APSA Council on the practices and policy for the annual Teaching and Learning Conference.

Term expiring August 31, 2019

Thomas Ellington, Wesleyan Collage

Elizabeth Smith, Furman University

Term expiring August 31, 2018

Alison McCartney, Towson University

Lee Trepanier, Saginaw Valley State University

Term expiring August 31, 2017

Stephen Meinhold, University of North Carolina, Wilmington, Chair

Desiree Pedescleaux, Spelman College

\section{Award Committees}

\section{CAREER AWARD COMMITTEES \\ APSA Distinguished Teaching Award}

Honors outstanding contributions to undergraduate and graduate teaching of political science at two-and four-year as well as graduate level institutions. It may recognize a series of contributions spanning several years, an entire career, or a single project of exceptional impact.
Term expiring August 31, 2017

Chair: Nancy Kassop, State University of New York, New Paltz

Welling Hall, Earlham College

Ethan Hollander, Wabash College

\section{Dahl Award}

The Robert A. Dahl Award is awarded annually to an untenured scholar who has produced scholarship of the highest quality on the subject of democracy. Non-ladder faculty members, junior tenure-track faculty at universities and colleges are eligible for the Dahl Award, as are scholars at nonprofit organizations and think tanks, and independent scholars

Term expiring August 31, 2017

Chair: Claire Adida, University of California, San Diego

Staffan Lindberg, Gothenberg University

Thad Williamson, University of Richmond

\section{John Gaus Lecture Committee}

Honors the recipient's lifetime of exemplary scholarship in the joint tradition of political science and public administration as well as recognizes achievement and encourages scholarship in public administration.

Term expiring August 31, 2017

Chair: Greg Lewis, Georgia State University

Ann Bowman, Texas A\&M University

Jocelyn Johnston, American University

\section{Frank J. Goodnow Award}

Recognizes distinguished service to the profession and the Association, but not necessarily a career of scholarship. This service may be by individuals, groups, and public and private organizations who have played a role in the development of the political science profession and the building of APSA.

Term expiring August 31, 2017

Chair: Priscilla Regan, George Mason University

Kyle Beardsley, Duke University

Jeff Frieden, Harvard University

\section{Hanes Walton, Jr. Career Award}

The Hanes Walton, Jr. Career Award is named in honor of the former APSA Vice President (2012-2013) and professor of political science at the University of Michigan. Given biennially, this award recognizes a political scientist whose lifetime of distinguished scholarship has made significant contributions to our understanding of racial and ethnic politics and illuminates the conditions under which diversity and intergroup tolerance thrive in democratic societies. 
Term expiring August 31, 2017

Chair: Alvin Tillery, Northwestern University

Michael Jones-Correa, University of Pennsylvania

Jane Junn, University of Southern California

\section{Hubert H. Humphrey Award Committee}

For recognition of notable public service by a political scientist.

Term expiring August 31, 2017

Chair: Mary Katzenstein, Cornell University

Michael Lipsky, Demos

Kent Weaver, Georgetown University/ Brookings Institution

\section{Benjamin E. Lippincott Award}

This award recognizes a work of exceptional quality by a living political theorist that is still considered significant after a time span of at least 15 years since the original publication (supported by University of Minnesota). Given biennially; next awarded in 2017

Term expiring August 31, 2017

Chair: Sarah Song, University of California, Berkeley

Corey Brettschneider, Brown University Cecile Laborde, University College, London

\section{James Madison Award Committee}

To recognize an American political scientist who has made a distinguished scholarly contribution to political science. The award is given triennially. The next award will be in 2017.

Term expiring August 31, 2017

Chair: Susan Stokes, Yale University

Helen Ingram, University of Arizona

Frank Thompson, Rutgers University

\section{Carey McWilliams Award Committee}

Honors a major journalistic contribution to our understanding of politics.

Term expiring August 31, 2017

Chair: Johanna Dunaway Texas A\&M University

Matt Baum, Harvard Kennedy School

Claes De Vreese, University of Amsterdam

\section{Charles Merriam Award}

Recognizes a person whose published work and career represent a significant contribution to the art of government through the application of social science research. Given biennially; next awarded in 2017

Term expiring August 31, 2017

Chair: Lisa Anderson, American University of Cairo
Donald Kinder, University of Michigan

Paul Quirk, University of British Columbia

\section{Ithiel De Sola Pool Award}

The Ithiel de Sola Pool Award and Lectureship was established in 1995 by the Association to honor the memory and contributions of Ithiel de Sola Pool. The award honors a scholar whose research explores a broad range of fields pursued by Ithiel de Sola Pool including political theory, political behavior, political communication, science and technology policy, and international affairs. The award is made triennially, and given next in 2016 It includes a \$200o prize, and the recipient delivers a lecture at the APSA Annual Meeting Given triennially; next awarded in 2019

\section{DISSERTATION AWARD \\ COMMITTEES}

Gabriel A. Almond Award Committee

For the best doctoral dissertation in the field of comparative politics.

Term expiring August 31, 2017

Chair: Kimuli Kasara, Columbia University

Daniel Ziblatt, Harvard University

Michael Ross, University of California Los Angeles

\section{William Anderson Award Committee}

For the best doctoral dissertation in the general field of federalism or intergovernmental relations, state and local politics.

Term expiring August 31, 2017

Chair: Nicole Bolleyer, University of Exeter

Michael Hail, Morehead State University

Shanna Pearson-Merkowitz, University of Rhode Island

\section{Edward S. Corwin Award Committee}

For the best doctoral dissertation in the field of public law.

Term expiring August 31, 2017 Chair: Jeff Staton, Emory University

Lori Johnson, Mercer University

Jeff Lax, Columbia University

\section{Harold D. Lasswell Award Committee}

For the best doctoral dissertation in the field of policy studies. The award is supported by the Policy Studies Organization and the APSA Organized Section on Public Policy.

Term expiring August 31, 2017

Chair: Jeronimo Cortina, University of Houston

Christine Rothmayr Allison, University of Montreal

Lisa Miller, Rutgers University

\section{E. E. Schattschneider Award Committee}

For the best doctoral dissertation in the field of American government.

Term expiring August 31, 2017

Chair: Gisela Sin, University of Illinois

at Urbana-Champaign

Julia Azari, Marquette University

Matthew Beckmann, University of California, Irvine

\section{Sherrill Prize}

Established in 2015 and supported by the Ken Sherrill Fund, a temporarily restricted fund within the APSA Centennial Center, the first Sherrill Prize, given in 2016, will recognize the best doctoral dissertation proposal for an empirical study of lesbian, gay, bisexual or transgender (LGBT) topics in political science.

Term expiring August 31, 2017

Ravi Perry, Virginia Commonwealth University

Term expiring August 31, 2018

Chair: Pat Egan, New York University, Chair

Term expiring August 31, 2019

Andrew Reynolds, University of North Carolina at Chapel Hill

\section{Leo Strauss Award Committee}

For the best doctoral dissertation in the field of political philosophy.

Term expiring August 31, 2017

Chair: Judith Grant, Ohio University

Arash Abizadeh, McGill University

Deborah Baumgold, University of Oregon

\section{Merze Tate Award Committee}

For the best dissertation sucessfully defended during the previous two years in the field of international relations, law, and politics.

Term expiring August 31, 2017

Chair: Jessica Chen Weiss, Cornell University

Terry Chapman, University of Texas, Austin

Victoria Tin-bor Hui, University of Notre Dame

\section{Leonard D. White Award Committee}

For the best doctoral dissertation in the field of public administration.

Term expiring August 31, 2017

Chair: Zachary Oberfield, Haverford College

Mary Feeney, Arizona State University

Holly Goerdel, University of Kansas 
PAPER OR ARTICLE AWARD

COMMITTEES

Franklin L. Burdette Pi Sigma Alpha Award Committee

For the best paper presented at the previous annual meeting.

Term expiring August 31, 2017

Chair: Jennifer Wolak, University of Colorado, Boulder

Carsten Jensen, Aarhus University

John Wilkerson, University of

Washington

\section{Heinz Eulau Award Committee}

For the best article published in APSR and Perspectives on Politics during the previous calendar year. Two Eulau Awards are made, one for each journal. Committee members are asked to help make the selection from one journal or the other, and the chair is asked to participate in both decisions.

Term expiring August 31, 2017

Chair: Florence Faucher, Sciences Po

American Political Science Review

Johannes Lindvall, Lund University

Elizabeth Markovits, Mount Holyoke

College

Perspectives on Politics

Ed Mansfield, University of

Pennsylvania

Leslie Schwindt-Bayer, Rice University

\section{BOOK AWARD COMMITTEES}

Ralph J. Bunche Award Committee

For the best scholarly work in political science published in the previous calendaryear which explores the phenomenon of ethnic and cultural pluralism.

Term expiring August 31, 2017

Chair: Keith Banting, Queens University Andrew Douglas, Morehouse College Victoria Hattam, The New School

\section{Gladys M. Kammerer Award Committee}

For the best political science publication in the previous calendar year in the field of US national policy.

Term expiring August 31, 2017

Chair: Janet Martin, Bowdoin College

Stephen Amberg, University of Texas, San Antonio

Traci Burch, Northwestern University

\section{Theodore J. Lowi Award}

The Theodore J. Lowi Award recognizes the author of a first book in any field of political science that shows promise of having a substantive impact on the overall discipline, regardless of method, specific focus of inquiry, or approach to subject. APSA and IPSA will administer and fund the Lowi Award in alternating years. The 2016 Lowi Award will be awarded at the 2016 IPSA World Congress of Political Science in Poznań, Poland. APSA will award it at the 2017APSA Annual Meeting in San Francisco, and will appoint the award committee chair, while IPSA will appoint the other two award committee members.

Term expiring August 31, 2017

Chair: Graham Wilson, Boston University

\section{Victoria Schuck Award Committee}

The Victoria Schuck Award is for the best book published in the previous calendar year on women and politics.

Term expiring August 31, 2017

Chair: Helen Kinsella, University of Wisconsin-Madison

Amy Alexander, University of Gothenberg

Zoe Oxley, Union College

\section{Woodrow Wilson Foundation Award Committee}

For the best book published in the United States during the previous calendar year on government, politics, or international affairs. The award is supported by the Woodrow Wilson Foundation.

Term expiring August 31, 2017

Chair: Edward Weber, Oregon State University

Benjamin Smith, University of Florida Mariah Zeisberg, University of Michigan. 